\title{
Mutagenesis and Triazine Herbicide Effects in Strawberry Shoot Cultures
}

\author{
R. P. MALONE ${ }^{1}$ and $P$ J. DIX ${ }^{2}$ \\ Department of Biology, St. Patrick's College, Maynooth, Co. Kildare, Ireland
}

Received 18 July 1989

\begin{abstract}
The effects of simazine on shoot culture of two varieties of strawberry were investigated with a view to establishing a system for in vitro selection of resistant mutants. In single shoots some chlorophyll loss occurred at herbicide levels producing little growth inhibition, but efficient bleaching was associated with severe suppression of growth. Varying simazine and sucrose levels, in both single and multiple shoot cultures did not reveal any conditions where chlorophyll destruction and growth inhibition could be separated. A protective effect, against bleaching, of high sucrose levels was not linked to suppression of photosynthesis, as assessed by $\mathrm{CO}_{2}$-fixation measurements. Mutagenesis with nitrosomethyl urea resulted in chlorophyll deficiencies in about $10 \%$ of shoots arising from axillary buds, but no resistant sectors emerged from 8000 and $\mathbf{4 0 0}$ mutagenized explants placed on medium containing inhibitory levels of simazine and streptomycin sulphate, respectively.
\end{abstract}

Key words: Strawberry, simazine, triazine, mutagenesis, shoot cultures.

\section{INTRODUCTION}

The extension of mutation breeding to embrace the in vitro culture technologies has been widely discussed and is the subject of several reviews (Flick, 1983; Maliga, 1984a; Dix, 1986, 1990). While there have been encouraging reports on the production of disease resistant (Jones, 1990) and environmental stress resistant (Nabors, 1990) plants through in vitro selection, it is probably in the area of herbicide resistance that the greatest progress has been made, albeit mostly with Nicotiana species (Chaleff and Parsons, 1978; Chaleff and Ray, 1984; Cséplö, Medgyesy, Hideg, Demeter, Márton, and Maliga, 1985). The last of these reports demonstrated that herbicides primarily effecting photosynthesis need not be excluded from this approach, despite the fact it is difficult to elicit the characteristic symptom of herbicide injury in typical, heterotrophic, tissue cultures (Gressel, Zilkah, and Ezra, 1978). These workers demonstrated (Cséplö and Medgyesy, 1986) that green, heterotrophic callus of Nicotiana plumbaginifolia was neither markedly inhibited in growth, nor bleached, by the inclusion of triazine herbicides in the culture medium. Lowering of the sucrose concentration, however, from 3.0 to $0.3 \%$ led to the development of photomixotrophic (partially photosynthetic) cultures, in which about $70 \%$ of biomass increase is dependent on photosynthesis. Under these conditions the triazine herbicides caused bleaching, permitting the selection of herbicide resistant mutants as green protoplast-derived colonies against a background of bleached ones (Cséplö et al., 1985).

Few crop species are as amenable to cell culture manipulations as Nicotiana. Strawberry (Fragaria ananassa Dutch.) is typical in that detailed reports on plant regeneration from protoplasts (Nyman and Wallin, 1988) and even from callus (Jones, Waller, and Beech, 1988) have only recently appeared and the frequencies are rather low for in vitro selection. Strawberry does, however, permit an extremely efficient micropropagation system, based on axillary bud development, which has been developed into a major method for commercial propagation (Boxus, Damiano, and Brasseur, 1984). The present report describes a series of experiments designed to investigate whether this multiple shoot culture system could provide the basis for in vitro selection for simazine resistance in strawberry. Clearly, mutagenesis of existing axillary buds

\footnotetext{
${ }^{1}$ Present address: Biochemistry Department, Rothamsted Experimental Station, Harpenden, Hertfordshire AL5 2JQ, UK.

2 To whom correspondence should be addressed.
}

(C) Oxford University Press 1990 
differs fundamentally from that of cells with a potential to differentiate into adventitious buds, and should give rise to chimeras (Hagemann, 1976; Tilney-Bassett, 1986). However, the extremely high efficiency of plastome mutagenesis by nitrosomethyl urea (Fluhr, Aviv, Galun, and Edelman, 1985; McCabe, Timmons, and Dix, 1989), together with the massive stimulation of axillary bud development, obtained through cytokinin-mediated release of apical dominance in strawberry shoot cultures (Malone and Dix, 1986), may ultimately lead to the production of solid mutant axillary shoots through the dissociation of the chimera. The success of this approach is dependent on there being sufficient time for the sorting out of resistant and sensitive plastids to give rise to resistant cell lineages, and an appropriate selection procedure for the identification of these. Even if solid mutant shoots do not appear there is the prospect of obtaining them indirectly, through adventitious shoot initiation from resistant selectors, as has been reported for Nicotiana tabacum (Radin and Carlson, 1978). In strawberry, adventitious shoots can be regenerated directly from leaf explants (Malone, 1988) or from callus (Jones et al., 1988) which may itself be initiated from resistant selectors.

Added impetus was given to the present study by the demonstration that chloroplast DNA encoded streptomycin resistant mutants can be selected with high efficiency in organogenic leaf explants of several species (McCabe et al., 1989). Triazine resistance is also a plastome encoded trait, being localized to the psbA gene coding for the 32 kD thylakoid protein (Goloukinoff, Edelman, and Hallick, 1984).

Simazine is widely used for the control of weeds in strawberry crops but there are considerable restrictions to its application, due to the susceptibility of the crop. The herbicide is unsuitable for use on young plants, or for spring applications when fine feeding roots facilitate its absorption by the plants. Introduction of genetic resistance to the triazine herbicides into strawberry would assist in the development of cheap, effective weed control procedures for this crop.

\section{MATERIALS AND METHODS}

Strawberry shoot cultures

Shoot cultures were established from axillary buds excised from field grown plants of octoploid strawberry varieties Clonderg and Clonard, kindly provided by J. B. McLachlan (Teagasc, Clonroche, Co. Wexford, Ireland). The buds were surfacesterilized by rinsing in $70 \%$ aqueous ethanol $(v / v)$ for $15-20 \mathrm{~s}$, followed by immersion in $5 \%$ sodium hypochlorite $(w / v)$ solutuon for $20 \mathrm{~min}$. The disinfected tissue was rinsed twice in sterile distilled water.

Buds were induced to develop into plantlets by transfer to a basal medium (RM) containing the inorganic salts of Murashige and Skoog (1962), supplemented with $3 \%(w / v)$ sucrose and solidified with $0.7 \%(\mathrm{w} / \mathrm{v})$ Difco Bactoagar. The $\mathrm{pH}$ of the medium was adjusted to 5.8 with $\mathrm{KOH}$. Under these conditions a normal shoot develops with a vigorous root system. Hereafter these cultures are referred to as single shoot cultures. Multiplication of shoots was induced by transferring axils to the same medium enriched with $10 \mathrm{mg} \mathrm{dm}^{-3}$ thiamine $\mathrm{HCl}, 100 \mathrm{mg} \mathrm{dm}^{-3}$ myo-inositol and $1.0 \mathrm{mg} \mathrm{dm}^{-3} 6$-benzylaminopunne (BAP), and designated RMB (Maliga, 1984b). On this medium a mass of shoots develops, usually with no rooting (cultures designated multiple shoot cultures).

Both single and multiple shoot cultures were grown at $25^{\circ} \mathrm{C}$ under a $16 \mathrm{~h}$ photoperiod $(1000 \mathrm{~lx})$ and subcultured by transferring axils to fresh RM or RMB medium, respectively, every $6-8$ weeks.

\section{Herbicide}

The triazine herbicide, simazine (provided by E. Fitzgerald, Ciba-Geigy, Co. Waterford, Ireland) was added to culture media, at final required concentrations, prior to autoclaving.

\section{Chlorophyll content}

The determination of the amount of total chlorophyll, chlorophyll a and chlorophyll b present in leaf tissue was based on Meidner (1984). $1.0 \mathrm{~g}$ tissue was ground in a mortar with a little sand. The material was then transferred to a $10 \mathrm{~cm}^{3}$ stoppered glass test tube and $4.0 \mathrm{~cm}^{3}$ acetone added. After vigorous shaking (10 s) the tube was allowed to stand for $10 \mathrm{~min}$ before the addition of $3.0 \mathrm{~cm}^{3}$ water and further shaking $(10 \mathrm{~s})$. Finally, $3.0 \mathrm{~cm}^{3}$ petroleum ether was added and, after further shaking $(5 \mathrm{~s})$ the solvents were allowed to separate. $1.0 \mathrm{~cm}^{3}$ of the top (petroleum ether) layer, in which the chlorophyll pigments accumulate, was diluted with $9.0 \mathrm{~cm}^{3}$ acetone and absorbance at 645 and $663 \mathrm{~nm}$ read on an Hitachi Perkin Elmer 139 spectrophotometer. The chlorophyll content ( $\mathrm{mg} \mathrm{g}^{-1}$ fresh weight) was determined using the equations of Arnon (1949).

\section{$\mathrm{CO}_{2}$-fixation rates}

$1.0 \mathrm{~cm}$ diameter discs were cut from leaves with a cork borer and placed abaxial side uppermost on wet filter paper in perspex chambers through which moist air was circulated. ${ }^{14} \mathrm{CO}_{2}$, released from $\mathrm{Ba}^{14} \mathrm{CO}_{3}$ (Amersham) by perchloric acid, was introduced to give a final concentration of $0.06 \% \mathrm{CO}_{2}$ and a specific activity of $3.77 \times 10^{4} \mathrm{~Bq} \mu \mathrm{mol}^{-1}$. After equilibration in the dark the leaf discs were illuminated for $1 \mathrm{~h}$ at $10000 \mathrm{~lx}$, dried in an oven for $2 \mathrm{~h}$ at $60^{\circ} \mathrm{C}$, and their radioactivity measured in an LKB, 1217 Rackbeta liquid scintillation counter. From the $\mathrm{dpm}$ values, $\mathrm{CO}_{2}$ fixation rates were calculated and expressed on $\mathrm{a} \mathrm{g}^{-1}$ fresh weight or $\mathrm{mg}^{-1}$ total chlorophyll basis.

\section{Mutagenesis}

Multiple shoots growing on RMB medium were dissected into smaller units (containing 5-10 axils) and suspended in a filtersterilized aqueous solution of nitrosomethyl urea (NMU), in $250 \mathrm{~cm}^{3}$ Erlenmeyer flasks. Flasks were incubated on a rotary shaker $\left(100 \mathrm{rev}\right.$. $\left.\mathrm{min}^{-1}\right)$ at $25^{\circ} \mathrm{C}$ for the required period. The mutagen solution was then decanted and the plant material washed three times with sterile water ( $\mathrm{pH} 5 \cdot 6-5 \cdot 8)$ before individual axils were dissected out, and transferred to either RM or RMB culture medium, with or without selective levels of herbicides or streptomycin. Full details of the precautions used when handling the mutagen are reported elsewhere (McCabe, Cséplō, Timmons, and Dix, 1990).

\section{RESULTS}

\section{Effect of simazine on growth and chlorophyll content of} shoot cultures

In order to establish simazine concentrations influencing both biomass accumulation and chlorophyll production, 
under routine culture conditions, the effects of including simazine, at various levels, in RM medium containing the usual $(3 \%)$ sucrose concentration was investigated. The results were similar for both varieties and are shown for 'Clonderg' in Fig. 1. Low simazine concentrations (up to $0.2 \mathrm{mg} \mathrm{dm}^{-3}$ ) have little effect on fresh weight but already produce a substantial reduction (to $50-60 \%$ ) in chlorophyll concentration. Higher concentrations result in a further reduction in chlorophyll level, in parallel with growth inhibition. Only at simazine levels $\left(2.0 \mathrm{mg} \mathrm{dm}^{-3}\right.$ and higher) causing severe growth inhibition is bleaching pronounced. Similar results (data not shown) were obtained using atrazine and terbutryne.

\section{Simazine/sucrose interactions in single and multiple shoot cultures}

In an effort to maximize the expression of the chlorophyll destructive effect of the herbicide, while reducing growth inhibition, shoot cultures were subjected to several simazine concentrations at a range of sucrose levels. Multiple shoot cultures were included in this investigation, as a system more suited to in vitro selection. Fresh weights and chlorophyll concentrations are presented, for variety Clonard in Fig. 2, and $\mathrm{CO}_{2}$ fixation rates for certain treatments in Table 1.

Vigorous growth of single shoot cultures, even in the absence of simazine, was dependent on high $(>0.3 \%)$

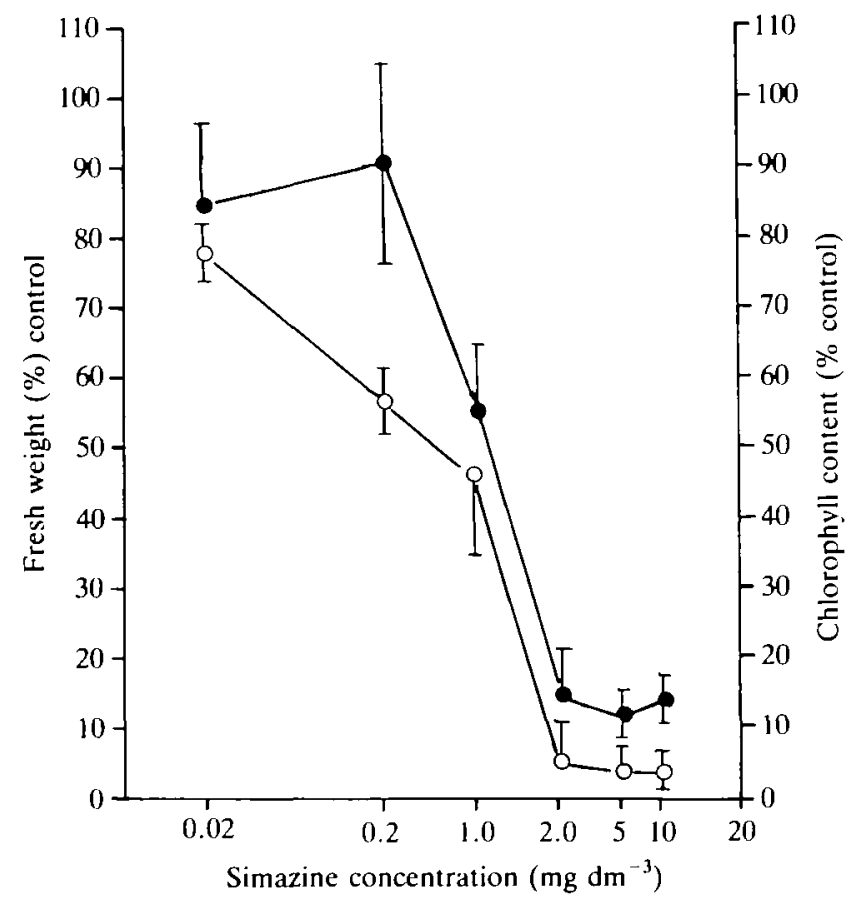

Fig. 1. Growth and chlorophyll content of single shoot cultures of strawberry genotype 'Clonderg' on medium containing a range of simazine concentrations. Values for fresh weight $(\bullet)$ and chlorophyll content (O) are percentage of control, cultures grown in the absence of simazine, measured 6 weeks after inoculation. Inoculum and final fresh weights of control cultures were 0.2 and $1.9 \mathrm{~g}$, respectively, and the final chlorophyll content was $2.2 \mathrm{mg} \mathrm{g}^{-1}$ fresh weight. Values are the mean of 20 replicates and the vertical bars represent \pm standard error of the mean.
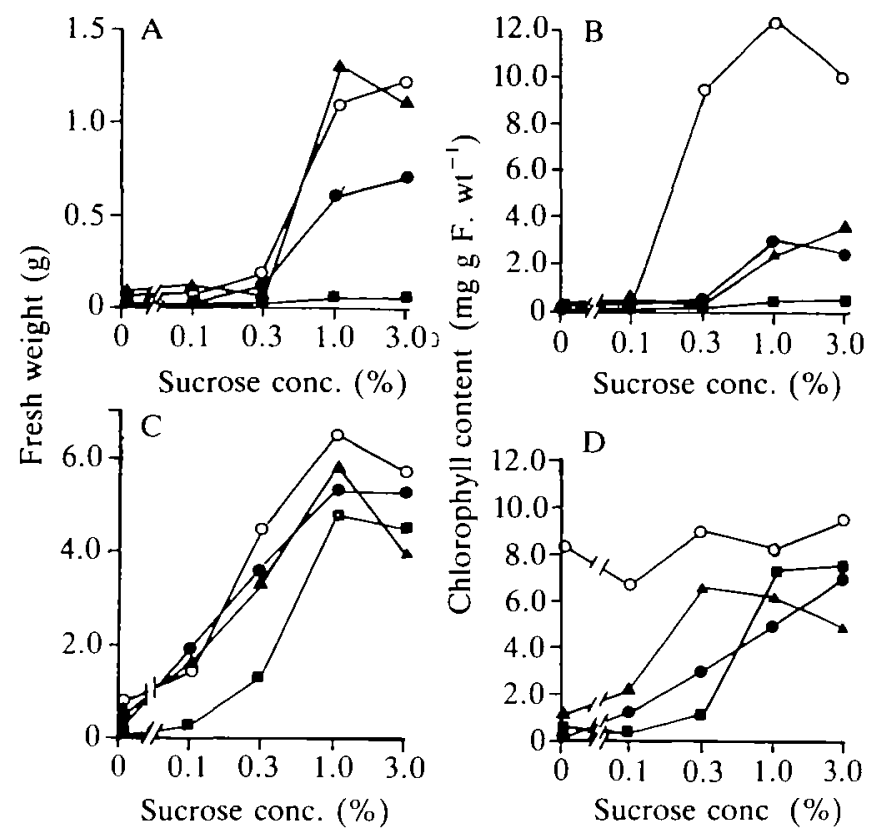

FIG. 2. Growth and chlorophyll content of single $(A, B)$ and multiple (C, D) shoot cultures of strawberry genotype 'Clonard' on media contaning a range of sucrose concentrations, at several different levels of simazine. Fresh weight $(A, C)$ and chlorophyll $(B, D)$ values were measured 6 weeks after inoculation. Simazine concentrations were $0(O)$, $1(\Delta), 2(\bullet)$ and $5(\boldsymbol{\nabla}) \mathrm{mg} \mathrm{dm}^{-3}$. All values are means of 30 replicates and standard errors did not exceed $15 \%$ of the mean.

sucrose supply, and on 0 or $0.1 \%$ sucrose most shoots were necrotic. At higher sucrose concentrations bleaching was only complete, i.e. plants resembled albinos except for slight yellowing, at the highest level of simazine used $\left(5.0 \mathrm{mg} \mathrm{dm}^{-3}\right)$, which also caused complete growth inhibition.

Multiple shoot cultures were less susceptible to both growth inhibition and chlorophyll destruction, by the herbicide at the higher sucrose levels. At intermediate concentrations of both sucrose $(0.1$ and $0.3 \%)$ and simazine $\left(2.0 \mathrm{mg} \mathrm{dm}^{-3}\right)$ there was evidence for chlorophyll destruction, while maintaining an acceptable growth rate, but bleaching was insufficiently complete to commend it as a system for in vitro selection. Further experiments using a higher $\left(10 \mathrm{mg} \mathrm{dm}^{-3}\right)$ simazine concentration showed a pronounced chlorotic effect, as well as almost complete growth inhibition in multiple shoot cultures (data not shown).

Variation in $\mathrm{CO}_{2}$ fixation rate (Table 1) was linked to chlorophyll level. Rates expressed on a per $\mathrm{mg}$ chlorophyll basis were all comparatively similar.

\section{Mutagenesis}

After mutagenesis with $10 \mathrm{~mol} \mathrm{~m} \mathrm{~m}^{-3} \mathrm{NMU}$ for $90 \mathrm{~min}$ explants were placed on RM or RMB medium without added drugs or with a selective level of simazine or streptomycin sulphate.

Multiple shoot cultures of both varieties, developing on 
TABLE 1. Carbon dioxide fixation rates in multiple shoot cultures of strawberry variety 'Clonard' grown on medium containing different concentrations of sucrose and simazine

Values represent the mean for five leaf dises $(10 \mathrm{~cm}$ diameter), illuminated $(10000 \mathrm{kx})$ for $1 \mathrm{~h}$ in an atmosphere containing $006 \% \mathrm{CO}_{2}$, including ${ }^{14} \mathrm{CO}_{2}$ at a specific activity of $3.77 \times 10^{4} \mathrm{~Bq} \mu \mathrm{mol}^{-1}$.

\begin{tabular}{|c|c|c|c|c|c|c|}
\hline \multirow{4}{*}{$\begin{array}{l}\text { Simazıne } \\
\left(\mathrm{mg} \mathrm{dm}^{-3}\right)\end{array}$} & \multicolumn{6}{|c|}{$\mathrm{CO}_{2}$ fixation } \\
\hline & \multicolumn{3}{|c|}{$\mu \mathrm{mol} \mathrm{g}^{-1}$ fresh wt. } & \multicolumn{3}{|c|}{$\mu \mathrm{mol} \mathrm{mg}{ }^{-1}$ chlorophyll } \\
\hline & \multicolumn{3}{|c|}{ Sucrose $(\%)$} & \multicolumn{3}{|c|}{ Sucrose $(\%)$} \\
\hline & $0-0$ & 0.3 & 3.0 & 00 & 0.3 & 30 \\
\hline $\begin{array}{l}0 \\
2 \\
5\end{array}$ & $\begin{array}{c}197 \pm 32 \\
5 \pm 2 \\
23 \pm 4\end{array}$ & $\begin{array}{c}150 \pm 29 \\
79 \pm 9 \\
27 \pm 4\end{array}$ & $\begin{array}{l}298 \pm 43 \\
133 \pm 19 \\
157 \pm 17\end{array}$ & $\begin{array}{l}23 \cdot 8 \pm 5 \cdot 1 \\
29-0 \pm 5 \cdot 2 \\
35 \cdot 1 \pm 4 \cdot 8\end{array}$ & $\begin{array}{l}17 \cdot 1 \pm 3 \cdot 8 \\
27 \cdot 2 \pm 4 \cdot 0 \\
22 \cdot 5 \pm 2 \cdot 1\end{array}$ & $\begin{array}{l}32 \cdot 1 \pm 6 \cdot 0 \\
18 \cdot 9 \pm 2 \cdot 2 \\
20 \cdot 4 \pm 3 \cdot 1\end{array}$ \\
\hline
\end{tabular}

RMB medium, showed a high frequency of chlorophylldeficient mutants (Table 2; Fig. 3), attesting to the efficiency of the mutagenesis protocol. Selective conditions chosen for simazine resistance were $5 \cdot 0 \mathrm{mg} \mathrm{dm}^{-3}$ simazine in $\mathrm{RM}$ medium and $10 \mathrm{mg} \mathrm{dm}{ }^{-3}$ in RMB medium, using both high $(3 \%)$ and low $(0.3 \%)$ sucrose concentrations. From a total of 8000 mutagenized explants, and 8000 nonmutagenized explants, placed on simazine containing medium no stable, green, simazine resistant shoots were obtained. Furthermore, no streptomycin-resistant mutants were obtained from 400 each of mutagenized and non-mutagenized explants placed on RMB medium containing $500 \mathrm{mg} \mathrm{dm}^{-3}$ streptomycin sulphate, which causes efficient bleaching and $90 \%$ growth reduction in strawberry shoot cultures (Dix, unpublished).

\section{DISCUSSION}

This investigation was initiated to test the view that the efficient micropropagation systems established for species

TABLE 2. The occurrence of chlorophyll deficient mutations in multiple shoot cultures treated with $10 \mathrm{~mol} \mathrm{~m}^{-3} \mathrm{NMU}$ for $90 \mathrm{~min}$

After mutagenesis, explants were placed on RMB medium and examined after 4 weeks. No albino or variegated plants were found in nonmutagenized controls. Each row represents a separate experiment

\begin{tabular}{llll}
\hline Genotype & \multicolumn{2}{l}{ No. shoots } & \\
\cline { 2 - 4 }-- & Green & Variegated & Albino \\
'Clonard' & -429 & 32 & 2 \\
& 132 & 21 & 0 \\
& 261 & 24 & 3 \\
& 242 & 90 & 1 \\
& 779 & 66 & 2 \\
Percentage no. shoots & 596 & 88 & 3 \\
\cline { 2 - 4 } 'Clonderg' & & $11 \cdot 58$ & $0-40$ \\
\cline { 2 - 4 } & 369 & 38 & 1 \\
& 498 & 61 & 3 \\
& 433 & 47 & 0 \\
Percentage no. shoots & 486 & 39 & 0 \\
\hline
\end{tabular}

like strawberry, might be adaptable to provide a procedure for in vitro mutagenesis and selection for a valuable agronomic trait, triazine resistance, encoded on the chloroplast DNA. In the event, although the symptoms of herbicide injury could be expressed in the shoot cultures, and mutagenesis resulted in efficient generation of chlorophyll deficient mutants, no triazine resistant mutants could be obtained using this approach. We believe the problem lies not in the induction of resistant mutations but in the selection procedure.

In vitro selection protocols for resistance to a range of herbicides effecting photosynthesis (Cséplō et al., 1985), in common with aminoglycoside antibiotics (Maliga, Szidonia-Breznovits, and Márton, 1973; Cséplö and Maliga, 1982; Hamill, Ahuja, Davey, and Cocking, 1986), have certain peculiarities consequent upon the site of the mutation, (the chloroplast DNA) and the primary symptom (bleaching) produced by these chemicals. Successful isolation of mutants was dependent upon establishing conditions where bleaching was not accompanied by severe growth limitation. This certainly relates to the complex 'kiloploid' (Medgysey, 1990) nature of the plant's chloroplast genome, in which expression of a character not exhibiting strong dominance requires a protracted period of sorting out at three levels: between cpDNA molecules within a single chloroplast, among chloroplasts within a cell, and finally between resistant and sensitive cells. The first two of these may depend on continued proliferation of the cell mass, as is the case in the aforementioned protocols based on callus or protoplastderived colonies, and also in seedling selection systems (Fluhr et al., 1985). However, it has now been shown (McCabe et al., 1989) that streptomycin-resistant mutants can be obtained with extremely high frequency (over $70 \%$ of explants responding in the case of Solanum nigrum) as green adventitious shoots on leaf explants in which growth is almost completely suppressed. This approach was dependent, as were seedling based methods (Fluhr et al., 1985) on the use of an efficient plastome targeted mutagen, nitrosomethyl urea (Hagemann, 1982).

In evaluating strawberry shoot cultures, as a system for 


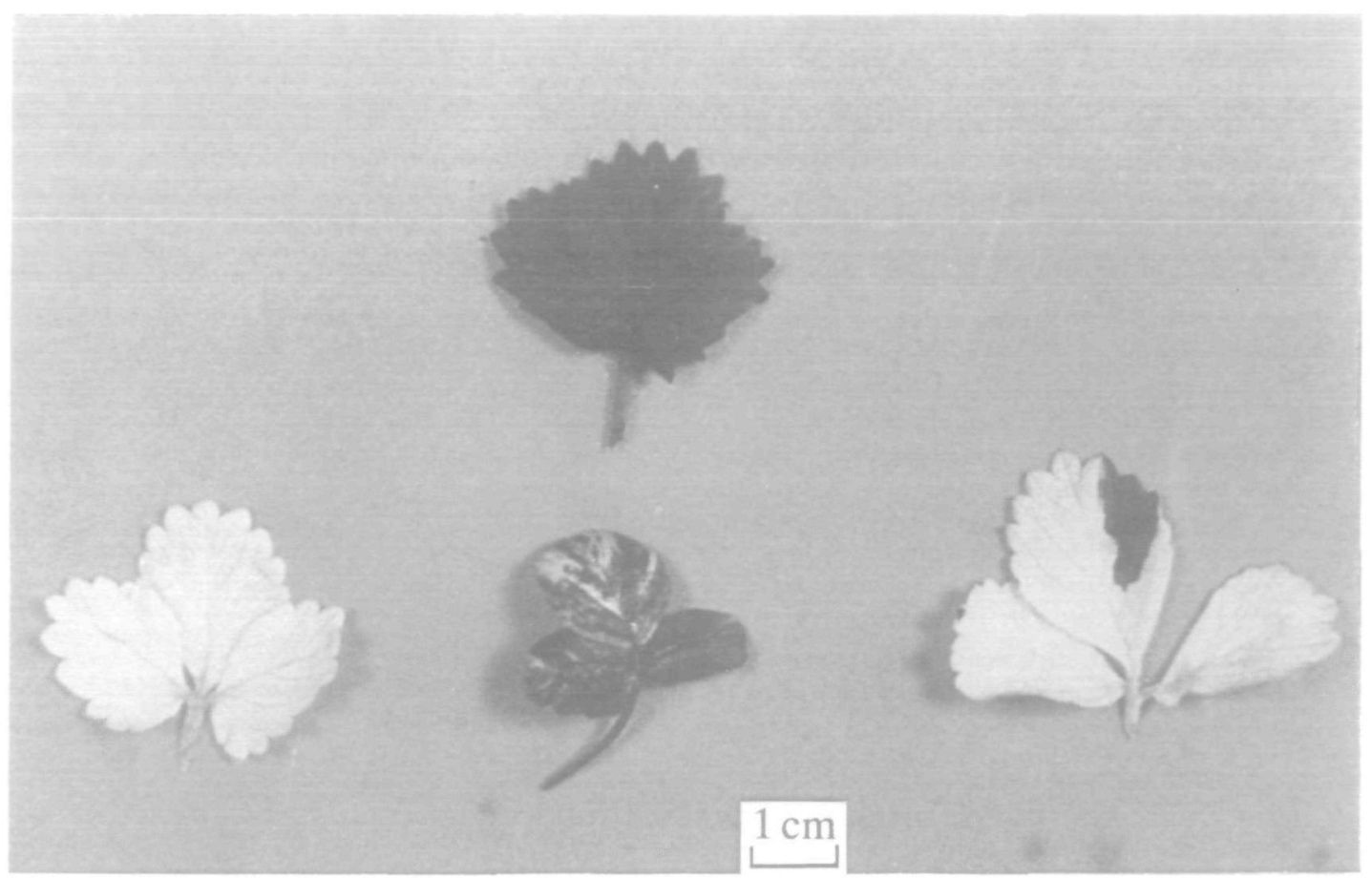

FIG. 3. Mutations induced by nitrosomethyl urea in shoot cultures of strawberry genotype 'Clonard'. A wild type leaf (top) is shown with leaves from an albino (left), and two variegated mutants.

selection for resistance to triazine herbicides, our first step was to investigate the effects of the herbicide at a range of sucrose concentrations. This was carried out since, in contrast to the aminoglycoside antibiotics, these herbicides require not only green, but photosynthetically active tissue to exhibit their characteristic photodestruction of chlorophyll (Cséplö and Medgyesy, 1986). Furthermore, high exogenous sugar levels, of the kind routinely supplied to strawberry shoot cultures, could provide a protective effect against the herbicides (Moreland and Hilton, 1976), presumably by inhibiting photosynthesis. Out results show a protective effect of high sucrose concentrations against herbicide-induced bleaching, particularly in multiple shoot cultures. There is no evidence, however, that this is due to inhibition of photosynthesis, since $\mathrm{CO}_{2}$ fixation rates were roughly proportional to chlorophyll concentration and not influenced by the sucrose level. These results contrast with previous observations on disorganized callus cultures of Nicotiana spp. (Cséplö and Medgyesy, 1986). The partial protective effect observed in the present study could relate to the greater vigour of cultures grown on high sucrose, combined with relatively poor uptake of the herbicide in multiple shoot cultures lacking roots.

The results favoured the use of lower sucrose levels at which herbicide-induced bleaching was more pronounced. However, these levels proved highly inhibitory to the growth and development of the cultures. In fact, no conditions were found in which thorough bleaching was associated with vigorous proliferation of shoot cultures, such as would permit a mutagenesis and selection procedure comparable with the tobacco seed mutagenesis system of Fluhr et al. (1985). Instead, in the hope that sorting out could occur despite growth suppression in axillary buds, as has been shown in adventitious buds (McCabe et al., 1989a), mutagen-treated axillary explants were placed on several herbicide-containing media causing overall growth inhibition, and bleaching of the explant.

The mutagenesis treatment was effective, as demonstrated by the high frequency (about $10 \%$ ) of variegated or albino plants appearing on non-selective medium. In fact, this is far greater than the frequency with which chlorophyll-deficient mutants from morphogenic leaf strips, which generate streptomycin-resistant mutants at high efficiency (McCabe et al., 1989). While these mutations have not been assigned to nuclear or cpDNA, the high incidence of sectoral chimeras is consistent with the preferential cpDNA targeting of nitrosomethyl urea (Hagemann, 1982), although this mutagen can also cause nuclear encoded chlorophyll deficiencies (Hosticka and Hanson, 1984).

The failure to obtain any herbicide-resistant shoots from over 8000 mutagen-treated explants suggests inefficient sorting out of the mutations in cpDNA of the axillary buds. The failure even to obtain streptomycin-resistant mutants is particularly instructive in view of the relative ease with which such mutants can be isolated using several 
different approaches (Maliga et al., 1973; Fluhr et al., 1985; McCabe et al., 1989, 1990). It appears that the cytological events occurring during the release of dormancy of axillary buds in strawberry do not favour the sorting out of resistant cpDNA molecules, if their subsequent growth is severely inhibited. In contrast, this sorting out process readily occurs in the cells from which adventitious shoots differentiate. The reason for this difference probably relates to the multicellular nature of the axillary bud, but may also involve the dramatic changes in plastid number, and cpDNA copy number occurring during chloroplast development, in the transition from a meristematic to a photosynthetic cell (Mullet, 1988). One encouraging feature of these experiments was that it was possible to obtain solid albino shoots using this protocol, although variegated shoots were much more frequent. Unless adventitious buds are being inadvertently generated by the culture conditions, this suggests that rapid axillary bud proliferation can lead to dissociation of the chimeras.

On the basis of our results multiple shoot cultures of strawberry, and perhaps other comparable systems, will only be appropriate for in vitro selection for triazine herbicide resistance if conditions are established in which rapid proliferation of the cultures occurs despite herbicide-induced bleaching. In the absence of such conditions alternative culture systems, such as morphogenic explants, callus, or protoplast-derived colonies, might prove more promising. Recent improvements in the potential for regeneration from such cultures (Malone and Dix, 1986; Malone, 1988; Jones et al., 1988; Nyman and Wallin, 1988) could also make strawberry a target for the exciting new prospects of genetically engineering crop plants for atrazine resistance. Already resistant tobacco plants have been obtained by Agrobacterium-mediated transformation using the psbA gene from an atrazine resistant biotype of Amaranthus hybridus (Cheung, Bogorad, Van Montagu, and Schell, 1988). In order to permit expression of this chloroplast gene in the nucleus it was spliced to expression signals from a nuclear gene, and base sequences coding for a transit peptide. Another possible route to atrazine resistance could be the production of transgenic plants expressing a gene for an enzyme, glutathione-S-transferase, which detoxifies atrazine (Shah, Hironaka, Wiegand, Harding, Krivi, and Tiemeier, 1986).

\section{LITERATURE CITED}

ARnon, D. T., 1949. Copper enzymes in isolated chloroplasts; polyphenoloxidases in Beta vulgaris. Plant Physiology, 24, 1-5.

Boxus, P., Damiano, C., and Brasseur, E., 1984. Strawberty. In Handbook of plant cell culture, Volume 3. Crop species. Eds P. V. Ammirato, D. A. Evans, W. R. Sharp and Y. Yamada. Macmillan, New York. Pp. 453-86.

ChalefF, R. S., and Parsons, M. F., 1978. Direct selection in vitro for herbicide-resistant mutants of Nicotiana tabacum. Proceedings of the National Academy of Sciences, USA, 75, 5104-7.
_ and RAY, T. B., 1984. Herbicide-resistant mutants from tobacco cell cultures. Science, 223, 1148-51.

Cheung, A. Y., Bogorad, L., Van Montagu, M., and Schell, J., 1988. Relocating a gene for herbicide tolerance: a chloroplast gene is converted to a nuclear gene. Proceedings of the National Academy of Sciences, USA, 85, 391-5.

Cséplö, A., and Maliga, P., 1982. Lincomycin resistance, a new type of maternally inherited mutation in Nicotiana plumbaginifolia. Current Genetics, 6, 105-9.

- and MEDGYesY, P., 1986. Characteristic symptoms of photosynthesis inhibition by herbicides are expressed in photomixotrophic tissue cultures of Nicotiana. Planta, 168, 24-8.

- Hideg, E., Demeter, S., Mírton, L., and Maliga, P., 1985. Triazine-resistant Nicotiana mutants from photomixotrophic cell cultures. Molecular and General Genetics, 200, 508-10.

Dix, P. J., 1986. Cell line selection. In Plant cell culture technology. Ed. M. M. Yeoman. Blackwell Scientific, Oxford. Pp. 143-201.

1990. (Ed.) Plant cell line selection. VCH Publishers, Weinheim (in press).

FLICK, C. E., 1983. Isolation of mutants from cell culture. In Handbook of plant cell culture, Volume 1. Techniques for propagation and breeding. Eds D. A. Evans, W. R. Sharp, P. V. Ammirato, and Y. Yamada. Macmillan, New York. Pp. 393-441.

Fluhr, R., Aviv, D., Galun, E., and Edelman, M., 1985. Efficient induction and selection of chloroplast encoded antibiotic resistant mutants in Nicotiana. Proceedings of the National Academy of Sciences, USA, 82, 1485-9.

Goloukinoff, P., Edelman, M., and Hallick, R. B., 1984. Chloroplast coded atrazine resistance in Solanum nigrum: psbA loci from susceptible and resistant biotypes are isogenic except for a single codon change. Nucleic Acids Research, 12, 9489-96.

Gressel, J., Zilkah, S., and Ezra, G., 1978. Herbicide action, resistance and screening in cultures versus plants. In Frontiers of plant tissue culture. Ed. T. A. Thorpe. IAPTC 1978 Calgary. Pp. 427-36.

HagemanN, R., 1976. Plastid distribution and plastid competition in higher plants and the induction of plastome mutations by nitroso-urea compounds. In Genetics and biogenesis of chloroplasts and mitochondria. Eds T. Buchner, W. Neupert, W. Sebald, and S. Werner. Elsevier Biomedical Press. Amsterdam. Pp. 331-8.

- 1982. Induction of plastome mutations by nitroso urea compounds. In Methods in chloroplast molecular biology. Eds M. Edelman, R. B. Hallick and N.-H. Chua. Elsevier Biomedical Press, Amsterdam. Pp. 119-27.

Hamill, J. D., Ahuja, P. S., Davey, M. R., and Cocking, E. C., 1986. Protoplast derived streptomycin resistant plants of the forage legume, Onobrychis viciifolia Scop. (sainfoin). Plant Cell Reports, 5, 439-41.

HostickA, L. P., and Hanson, M. R., 1984. Induction of plastic mutations in tomatoes by nitrosomethyl urea. Journal of Heredity, 75, 242-6.

Jones, O. P., Waller, B. J., and BeEch, M. G., 1988. The production of strawberry plants from callus cultures. Plant Cell Tissue and Organ Culture, 12, 235-41.

JONES, P. W., 1990. In vitro selection for disease resistance. In Plant cell line selection. Ed. P. J. Dix. VCH Publishers, Weinheim (in press).

MCCABE, P. F., Timmons, A. M., and Dix, P. J., 1989. A simple procedure for the isolation of streptomycin-resistant plants in Solanaceae. Molecular and General Genetics, 216, 132-7. 
Cséplō, A., Timmons, A. M., and Dix, P. J., 1990. Selection of chloroplast mutants. In Methods in molecular biology. Volume 6. Plant tissue culture. Eds J. M. Walker and J. W. Pollard. Humana Press (in press).

Malone, R. P., 1988. In vitro selection and transfer of chloroplast mutants in higHer plants. Ph.D. Thesis, National University of Ireland.

- and Dix, P. J., 1986. Selection for herbicide resistance in tissue cultures of Fragaria and Nicotiana. In Plant tissue culture and its agricultural applications. Eds L. A. Withers and P. G. Alderson. Butterworths, London. Pp. 479-86.

MaligA, P., 1984a. Isolation and characterization of mutants in plant cell culture. Annual Review of Plant Physiology, 35, $519-42$.

- 1984b. Cell culture procedures for mutant selection and characterization in Nicotiana plumbaginifolia. In Cell culture and somatic cell genetics of plants, Volume 1. Ed. I. K. Vasil. Academic Press, New York. Pp. 552-61.

- Szidonia-Breznovits, A., and MárTon, L., 1973. Streptomycin-resistant plants from callus cultures of haploid tobacco. Nature New Biology, 244, 29-30.

MEDGYESY, P., 1990. Selection and analysis of cytoplasmic hybrids. In Plant cell line selection. Ed. P. J. Dix. VCH Publishers, Weinheim (in press).

MeIDNer, H., 1984. Class experiments in plant physiology. George Allen and Unwin Ltd., London.

Moreland, D. E., and Hilton, J. L., 1976. Actions on photo- synthetic systems. In Herbicides: physiology, biochemistry, ecology, Volume 1. Ed. L. J. Audus. Academic Press, London, New York. Pp. 493-523.

Mullet, J. E., 1988. Chloroplast development and gene expression. Annual Review of Plant Physiology and Plant Molecular Biology, 39, 475-502.

Murashige, T., and Skoog, F., 1962. A revised medium for rapid growth and bioassays with tobacco tissue cultures. Physiologia plantarum, 15, 473-97.

Nabors, M. W., 1990. Environmental stress resistance. In Plant cell line selection. Ed. P. J. Dix. VCH Publishers, Weinheim (in press).

Nyman, M., and Wallin, A., 1988. Plant regeneration from strawberry (Fragaria ananassa) mesophyll protoplasts. In Progress in plant protoplast research. Eds K. J. Puite, H. J. Huizing, A. J. Kool, M. Koorneef and F. A. Krens. Kulver Academic Publishers, Dordrecht, Boston, London. Pp. 101-2.

RAdIN, D. N., and CARLSON, P. S., 1978. Herbicide-tolerant tobacco mutants selected in situ and recovered by regeneration from cell culture. Genetics Research, 32, 85-9.

Shah, D. M., Hironaka, C. M., Wiegand, R. C., Harding, E. J., Krivi, G. G., and Tremeier, D. C., 1986. Structural analysis of a maize gene coding for glutathione $S$-transferance involved in herbicide detoxification. Plant Molecular Biology, 6, 203-11.

Tilney-BAssett, R. A. E., 1986. Plant chimeras. Edward Arnold, London. 